\title{
Designing Just Transition Pathways: A Methodological Framework to Estimate the Impact of Future Scenarios on Employment in the French Dairy Sector
}

\author{
Pierre-Marie Aubert ${ }^{1, *}$, Baptiste Gardin ${ }^{1}$, Élise Huber ${ }^{1}$, Michele Schiavo ${ }^{1}$ and Christophe Alliot ${ }^{2}$ \\ 1 Institute for Sustainable Development and International Relations (Iddri), 41 rue du Four, 75007 Paris, France; \\ baptiste.gardin@iddri.org (B.G.); elise.huber@iddri.org (É.H.); michele.schiavo@iddri.org (M.S.) \\ 2 Bureau d'Analyse Sociétale Pour une Information Citoyenne (BASIC), 38 rue Saint Sabin, 75011 Paris, France; \\ christophe@lebasic.com \\ * Correspondence: pierremarie.aubert@sciencespo.fr; Tel.: +33-677-076-702
}

Citation: Aubert, P.-M.; Gardin, B.; Huber, É.; Schiavo, M.; Alliot, C. Designing Just Transition Pathways: A Methodological Framework to Estimate the Impact of Future Scenarios on Employment in the French Dairy Sector. Agriculture 2021, 11, 1119. https://doi.org/10.3390/ agriculture11111119

Academic Editors: David Barling, Antonella Samoggia and Guðrún Ólafsdóttir

Received: 10 September 2021

Accepted: 30 October 2021

Published: 10 November 2021

Publisher's Note: MDPI stays neutral with regard to jurisdictional claims in published maps and institutional affiliations.

Copyright: (c) 2021 by the authors. Licensee MDPI, Basel, Switzerland. This article is an open access article distributed under the terms and conditions of the Creative Commons Attribution (CC BY) license (https:// creativecommons.org/licenses/by/ $4.0 /)$

\begin{abstract}
This paper proposes an innovative framework to describe sustainable transitions of food systems while considering simultaneously socio-economic and environmental issues, in a just transition perspective. This framework (i) describes the structural changes needed for a sustainable transition in food systems; (ii) assess their effects on employment at the farm and processing industry level; (iii) detect the political levers needed to make this transition a just one-that is, preserving jobs and livelihoods for communities. Using the decarbonation pathway for the agricultural sector issued from the French National Low-Carbon Strategy as reference, we developed two scenarios for the French dairy sector which have the same level of climate ambitious, but a different approach to reach the target. Aiming exclusively to achieve a greenhouse gases reduction, the first scenario relies only on supply side measures. This scenario has a negative impact in terms of employment loss at the farm level and in the agri-food sector. In contrast, a multifunctional scenario considering simultaneously climate, biodiversity, health, and employment issues, and playing with policy measures targeting supply, demand and market organisation can maintain jobs in the farm and agri-food sector, contributes to restore the agro-biodiversity and develops food products compatible with healthy nutritional guidelines.
\end{abstract}

Keywords: just transition; dairy value chain; decarbonization; agri-food sector; modelling framework; farm jobs; agri-food jobs; French national low-carbon strategy

\section{Introduction}

The environmental impacts of the European food system are well established: they concern simultaneously biodiversity loss (within and outside Europe), soil degradation, greenhouse gases emissions and water bodies degradation [1,2]. Bringing the EU food system back within planetary boundaries [3,4] would imply-amongst other things-a strong protein transition [5,6], whereby the amount of animal protein production and consumption strongly decreases, while at the same time the environmental impacts of livestock productions systems are reduced $[1,2,7,8]$.

Although there is a strong scientific consensus regarding what needs to be done from a biophysical point of view, massive questions remain on how to make such a protein transition a just one-that is, while maintaining jobs and livelihoods for the concerned communities [9]. This question is even more central in the EU since the livestock sector represents roughly a third of all direct employments of the agri-food industry (out of 4.5 million jobs) and $45 \%$ of the total agricultural activity [10]. This industry is also nowadays the most important manufacturing industry in the EU in terms of direct employment and GDP creation, and the only industry that has resisted relocation over the last four decades [11]. The economic importance of the sector probably partly explains the strong 
pushback expressed by most economic and political actors against any concrete measures that would lead to a reduction in the livestock sector [12]. Thus, despite the ambitious announcement of the recently published Farm2Fork Strategy, part of the EU Green Deal, regarding the need to reduce the consumption of red and processed meat [13], there is still no single measure nor concrete targets or measures to reduce animal production in the EU [14].

This situation stems-at least partly-from the lack of scientific approaches to apprehend-and thus tackle - the socio-economic implications of environmentally sustainable transitions. The widely used socio-economic models which capture the impacts of transitions can only consider marginal changes to the food system [15]. This means that they cannot deal with scenarios involving biophysical breakthroughs, although such scenarios are necessary if we are to bring back the food system within planetary boundaries $[7,16]$.

Conversely, models specialised in exploring biophysical transformations are unable to capture their socio-economic impacts $[15,17]$. While different attempts have been made to develop ecological macroeconomics frameworks [18,19], they have been mainly applied to the energy sector and the agri-food sector has so far not been analysed through such a lens. Against this backdrop, this paper has a twofold objective:

- To present an original theoretical and methodological framework to apprehend the implications of sustainable food system scenarios on jobs, and thus identify the policy and social conditions under which such scenarios could be economically viable and socially acceptable;

- To present the key results of a research carried out applying this framework to the French dairy sector, following the indicative pathways outlined in the French national low carbon strategy [20].

The remainder of this paper is organized as follows. In Section 2, we present our analytical framework, the data collection strategy, and the case study. Section 3 presents the main results of the analysis while Section 4 discusses the main policy and scientific implications of our research.

\section{Materials and Methods}

\subsection{Case Study: Analyzing the Conditions of a Just Low Carbon Transition for the French Dairy Sector}

This paper is based on the projections for the agricultural sector contained in the National Low-Carbon Strategy (SNBC). Published in 2020 by the French Ministry of Ecology [20], the strategy aims to reduce by 50\% greenhouse gas emissions from the agricultural sector by 2050, providing a series of intermediary targets by 2030 and 2040. These targets are based on a physical and agronomic description of the French agricultural system, in terms of land use, livestock, yields and associated production, and cover all sectors and sub-sectors. Among all sectors covered by the SNBC, we focused on the analysis of the dairy sector for its importance for the French economy in terms of land use, employment and total value added generated. Given the high level of uncertainty when assessing economic changes, we also chose to work with a 2030-time horizon rather than 2050. Besides, this time horizon is more adapted to engage stakeholders in the design of scenarios, as was done in this study (see below the methodology section).

The SNBC envisions a series of changes in that sector by 2030, playing with the four main levers of decarbonation of the AFOLU sector [21]: increasing efficiency to decrease GHG emissions per ton of milk produced; maintain or increase carbon sinks through the preservation of extensive grasslands and the development of temporary grasslands [22]; developing biomass-based renewable energy to substitute fossil fuels; and eventually decreasing the overall herd size to reduce further emissions. Table 1 shows the different technical levers and the extent to which their adoption is envisioned in the SNBC. Figure 1 shows the projected evolution of the dairy herd against historical trends and the evolution of the cattle herd. 
Table 1. Technical developments in livestock systems according to SNBC assumptions (Source: adapted from MTES, 2020 [20]).

\begin{tabular}{|c|c|c|c|}
\hline Dairy Farming & 2015 & 2030 & 2050 \\
\hline $\begin{array}{l}\text { Reduction of protein intake in } \\
\text { the feed (\% of animals } \\
\text { concerned) [22] }\end{array}$ & $65 \%$ & $80 \%$ & $100 \%$ \\
\hline $\begin{array}{c}\text { Reduction of enteric } \\
\text { fermentation through feed } \\
\text { additive (\% of animals } \\
\text { concerned) [22] }\end{array}$ & $0 \%$ & $30 \%$ & $90 \%$ \\
\hline $\begin{array}{l}\text { Increase lifespan of temporary } \\
\text { grasslands to } 5 \text { years (\% of } \\
\text { animals concerned) }\end{array}$ & $10 \%$ & $50 \%$ & $85 \%$ \\
\hline $\begin{array}{l}\text { Covering of slurry pits and } \\
\text { installing flares (\% of } \\
\text { undigested effluent) }\end{array}$ & $0 \%$ & $46 \%$ & $80 \%$ \\
\hline $\begin{array}{l}\text { Reduce age at first } \\
\text { calving-dairy cows }\end{array}$ & 33.1 months & 29 months & 28.2 months \\
\hline $\begin{array}{l}\text { Reduce age at first } \\
\text { calving—suckler cows }\end{array}$ & 36 months & 33 months & 32 months \\
\hline $\begin{array}{l}\text { Decrease average calf } \\
\text { mortality rate }\end{array}$ & $17 \%$ & $10 \%$ & $10 \%$ \\
\hline $\begin{array}{l}\text { Increase the proportion of } \\
\text { dairy herds on grass }\end{array}$ & $\begin{array}{l}\text { Proportion of dairy cows: } \\
\text { - } \quad \text { mostly grass-fed: } 16 \% \\
\text { - } \quad \text { mostly maize-fed: } 58 \%\end{array}$ & $\begin{array}{l}\text { Proportion of dairy cows: } \\
\text { - } \quad \text { mostly grass-fed: } 29 \% \\
\text { - } \quad \text { mostly maize-fed: } 54 \%\end{array}$ & $\begin{array}{l}\text { Proportion of dairy cows: } \\
-\quad \text { mostly grass-fed: } 45 \% \\
\text { - } \quad \text { mostly maize-fed: } 44 \%\end{array}$ \\
\hline
\end{tabular}

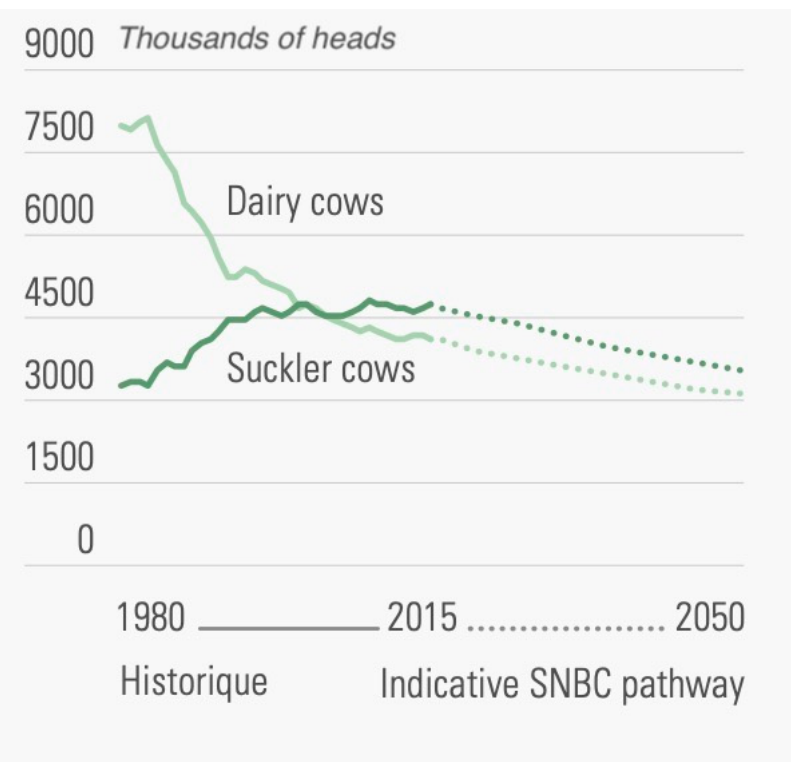

Figure 1. Evolution of the dairy and cattle herd as envisioned by SNBC with regard to the 1980-2015 dynamics (source: authors, based on MTES, 2020 [20]). SNBC: French national low carbon strategy.

Taken together, these changes imply a massive adaptation for the dairy sector, not only at the farm level (with a 11\% decrease in the overall number of dairy cows between 2015 and 2030), but also for the processing industry. The volumes and the geography of the production will also change, calling into question current supply and investment strategies and the investments needed at farm level, in a context of ageing of the farmer population and of constant increase in the capital intensity of farms. In this context, this paper provides public authorities and sector representatives reliable and transparent data regarding the potential consequences of the transition and on the most relevant accompanying measures that could be implemented. 


\subsection{Conceptual Framework: MOFOT, a MOdel of FOod Systems TRANSITION}

To do so, a conceptual model of food systems dynamics called MOdel of FOod systems Transitions (MOFOT) was developed. This model explores the socio-economic impacts of ambitious food system transformation scenarios and helps identifying the political and societal levers for a just transition. This original problematization led us to structure MOFOT as follows.

MOFOT takes as a starting point (box 1, Figure 2) an agronomic scenario at an aggregated level (the national or regional level), expressed in biophysical terms: land use, average yields, size of herds, adoption rate of specific mitigation measures.

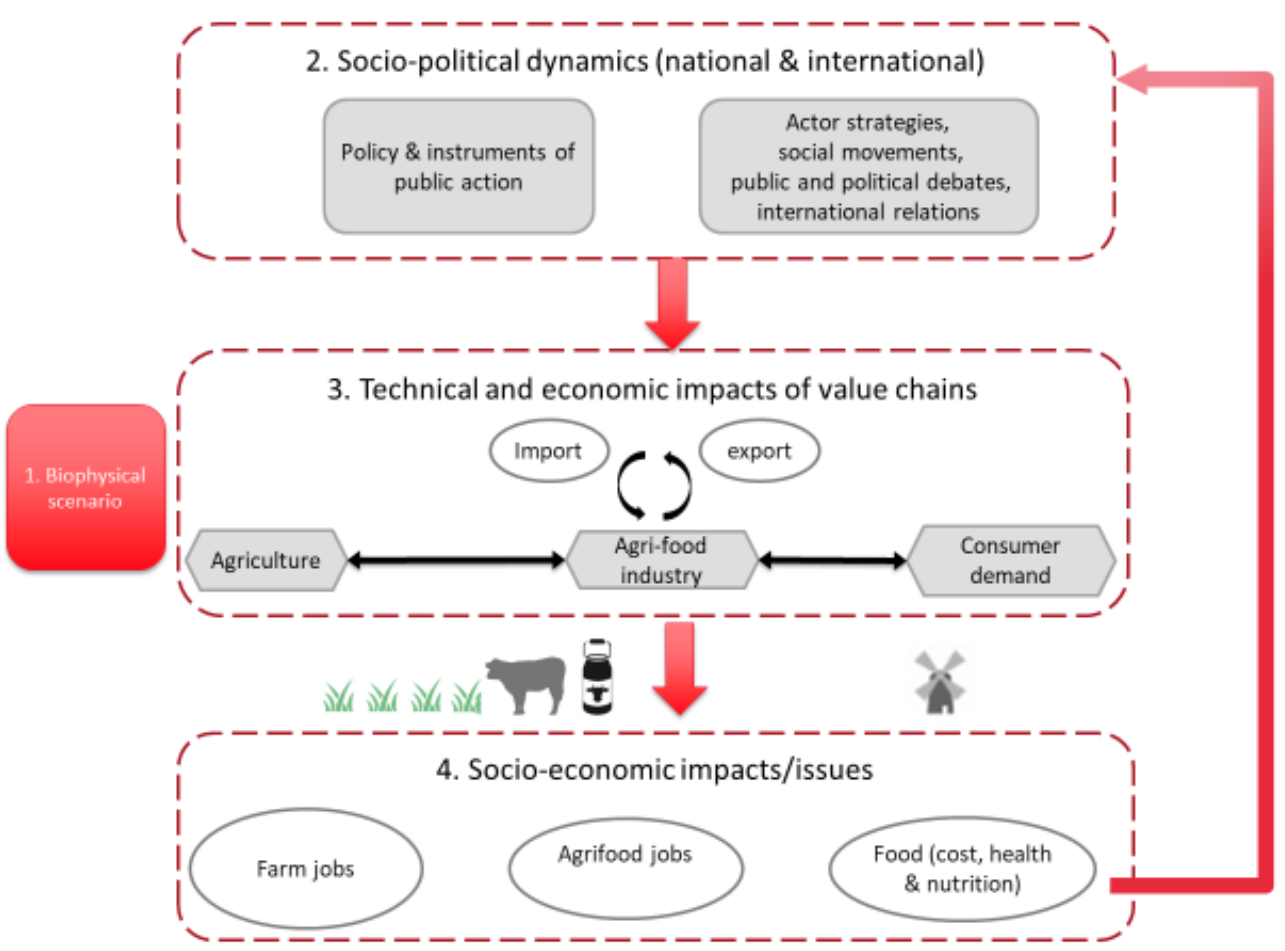

Figure 2. A simplified representation of MOFOT logical structure.

Then, MOFOT explores the potential transformation at farm, industry and consumer levels that are coherent both with the physical constraints set by the agronomic scenario, and with each other (i.e., making sure that hypotheses at the farm level are consistent with those at the industry and consumer levels, and vice et versa). Potential transformations are inferred based on broader socio-political narratives (box 2, Figure 2). They are expressed in techno-economic terms: variation in the amount of production factors (land, labour, capital) and changes in their allocation at the level of the production unit (box 3, Figure 2). Such an approach aims to capture the strategies of actors in the transition and to make an explicit link between physical flows and economic equilibria at the different stages of food chains.

Finally, using two simulation tools built in the MOFOT framework, namely SP_Calc and IAA_Calc, the impacts of the techno-economic changes envisioned at farm and industry levels on employment are assessed (box 4, Figure 2).Attempts were made to assess the implication for farmers' incomes but it proved extremely complex.

Figure 2 presents these four dimensions of MOFOT. Strategy changes by value chain actors follow broader socio-political dynamics (downward arrow from box 2 to box 3 ) and have impacts on the issues under consideration (downward arrow from box 3 to box 4). Feedback loops also exist. For example, public policies can be changed as a result of strategic repositioning of economic actors.

From an analytical point of view, MOFOT functions as a supply model predicting changes in agricultural supply under environmental constraints. However, three important 
differences distinguish MOFOT to other "classical" supply models such as MagPIE or AROPAj [23]:

- $\quad$ MOFOT is an exploration model, not an optimization model based on profit maximisation. It combines quantification and narratives to show how certain impacts are associated with different strategy changes, thereby elucidating trade-offs and synergies;

- MOFOT aims to understand the structural changes of production tools following the strategic choices of economic actors. Conversely, the most part of known models merely modify production functions under the assumption of technology adoption.

- Finally, like other supply-side models, MOFOT also gives particular attention to the representation of demand.

A key feature of this framework is that it enables to develop contrasted food system scenarios based on similar agronomic/biophysical scenarios and targets. In other words, for a given target of emission reduction (in this case, the one provided by the French low carbon strategy), several transition pathways can be envisioned.

In this paper, two transition pathways for the dairy sector are outlined and their socioeconomic consequences assessed using MOFOT. The storylines underpinning the two transition pathways are presented in the result section. Before that, precisions are provided regarding the way in which socio-economic consequences at farm and industry levels have been assessed. It is important to mention that we restrain the analysis to the French economic system. This means that the impact of the scenarios in terms of employment are only estimated for France and do not consider the possible transformations that they may generate in other countries as a consequence of French food system transformations. At the EU level, other member states will have to implement (or are already implementing) similar low carbon strategies in coherence with the FitFor55 package that has just been adopted in the framework of the Green Deal. Non-EU countries might also be affected if a carbon boarder adjustment mechanism is adopted and implemented for the agricultural sector.

\subsection{From MOFOT to SP_Calc and IAA_Calc: Assessing the Socio-Economic Impacts of Food System Transformations}

To assess the socio-economic impacts of a food system scenario, MOFOT is endowed with two simulation tools: SP_Calc (at the farm level) and IAA_Calc (at the processing industry level). These tools apprehend the impacts on employment of a given agronomic scenario by focusing on the physical labour intensity of the production [24]. Quirion et al [25] developed an analysis along similar lines based on the Afterres scenario [26]; they considered however the food industry as a whole and only apprehended the economic labour intensity of the production (e.g., how many jobs/1000 $€$ spent). At both levels, the general reasoning is similar and can be approached through Equation (1):

$$
\mathrm{L}=\mathrm{LI} \times \mathrm{Y}
$$

where $\mathrm{L}$ is the total labour force employed, LI the labour intensity, and $\mathrm{Y}$ an indicator of the total production relevant for the sector considered. $Y$ depends on the agronomic scenario taken as a starting point, while LI depends on production methods used at the economic unit level (the farm or the processing industry). These two indicators are determined following different methods at the farm and the industry level which are described below. In both cases, it entails a three steps approach:

(1) Characterise the current situation;

(2) Determine the value of the two indicators based on plausible and relevant assumptions regarding potential transformations of economic units

(3) Assess the impacts on employment.

This approach enables a clear identification of the farm type and industry sectors that are the most labour intensive, and which would need to be favoured in a just transition scenario that aims to address simultaneously environmental and socio-economic questions. 
To develop storylines and infer from these coherent assumptions regarding evolution of economic units (at the farm and industry levels), the overall approach proposed here relies on stakeholders workshops. Six such workshops were organised between September 2018 and June 2020 to develop and test potential evolution scenarios at farming system, industry, and consumer levels. Each workshop gathered between 15 and 25 actors coming from diverse background: farmer union representatives, technical institutes, industry representatives, retailers, NGOs (including consumer organizations), administrative bodies, and scientists. The first workshop (25 September 2018) aimed at presenting the overall study and approach; the second workshop (22 February 2019) aimed at validating the baseline; workshops 3 (17 September 2019) and 4 (9 April 2020) were used to test and adjust different set of assumptions at both farms, processing, and consumption levels. Finally, workshops 5 (12 June 2020) and 6 (17 July 2020) served to discuss the results, adjust the set of assumptions, and draw policy implications from the results.

\subsubsection{The Farm Level}

At the farm level, the characterization of the baseline relies on FADN data, a review of existing typologies as presented for the dairy and cattle sectors in [27] and expert interviews to establish a national-scale typology of existing farms. This typology is based on both agronomic and socio-economic variables, following the logic of farming system analysis [28]. Each farm type is characterised by its endowment in production factors (Usable Agricultural Area (UAA), fixed assets, labour force-both family and non-family one) as well as the main characteristics of technical itineraries (in particular feeding strategies for the dairy herd, crop rotation and share of permanent grassland in the UAA).

The second step consists in exploring potential evolutions of (existing farming systems and their combination at the sector level, by 2030 in the framework of the SNBC. The underlying hypothesis is that these evolutions are shaped by two key aspects: the situation of the farm as of today; and the farmer's strategy. Following Cerfrance, 2019 [29], two indicators are considered to apprehend farmers' strategies: the level of concentration (farm size) and the specialisation. Based on these two indicators, an evolution matrix combines four possible development strategies (Figure 3). A third additional indicator is considered to delineate the key characteristics of 2030 farming systems: the need for certain farms to adopt the practices identified by the SNBC to reduce emissions (Table 1).

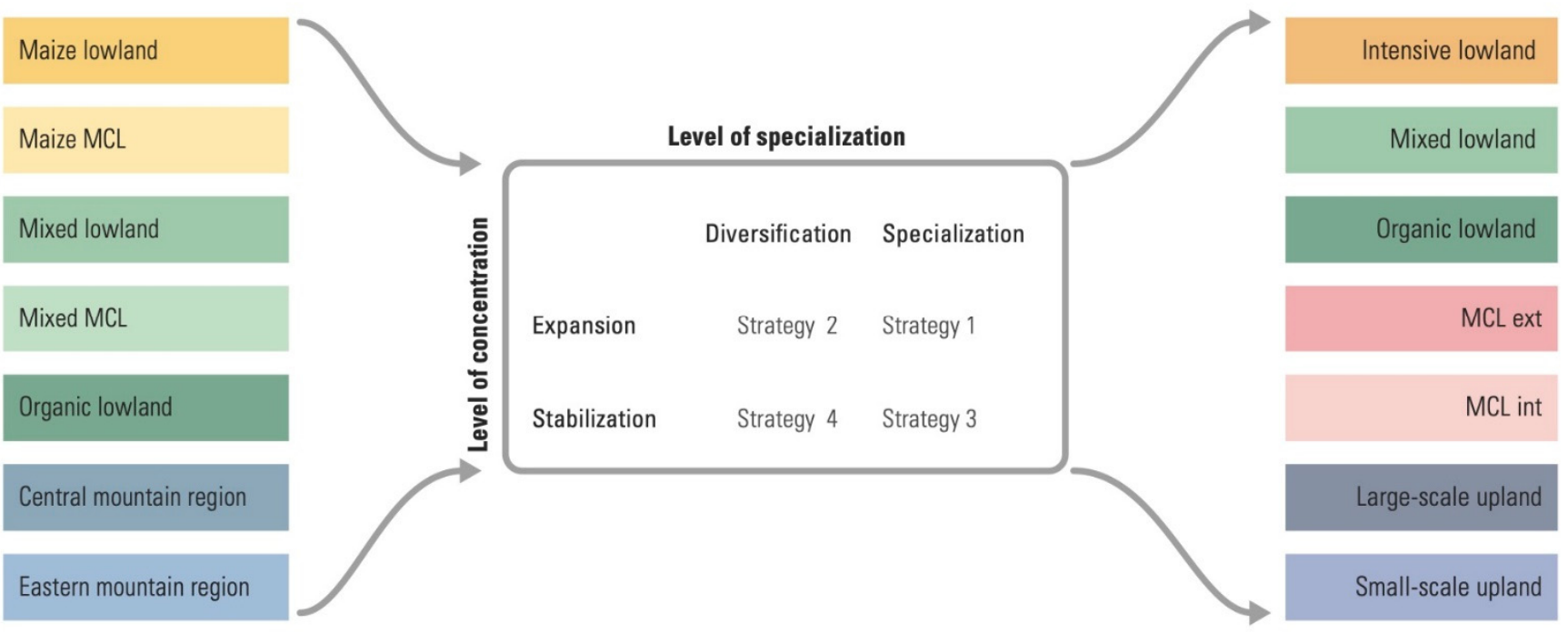

Figure 3. Analysing farming systems' potential evolution to 2030. MCL: Mixed crop-livestock systems; Ext: extensive; Int: intensive. 
- First, the set of possible combinations of the four development strategies and the 2015 types is considered.

- Then, the final types are generated by grouping similar types to keep the number of 2030 systems similar to the number of systems present in 2015.

- Finally, the quantitative characteristics of the resulting farms are estimated on the basis of innovative farms already present in FADN data and adjusted based on experts interviews and stakeholder workshops.

Through this approach, the labour intensity of the production can be approached for each type of farming system, expressed in terms of number of jobs per thousand litres of milk produced.

The third step of the analysis aims to construct populations of 2030 farming systems that are coherent with (i) the biophysical targets set by the SNBC, (ii) a set of more general assumptions derived from the broader socio-political storylines (e.g., average size, specialisation level, demographic framework, regionalisation criteria) and (iii) the plausibility of transitioning from one farm type to another one. The precise number of each type of farming system in the 2030 population is calculated by means of a Microsoft Excel solver that makes it possible to identify the solutions that respects all proposed assumptions. Once the 2030 farming system population is determined, the resulting number of jobs can be calculated from the labour intensity of each farming system:

$$
L_{2030}=\sum_{i}\left(L I-F S_{2030 i} \times F S_{2030 i}\right)
$$

where $L$ : total number of jobs, in annual work unit (AWU). $F S_{2030} i$ : number of type $i 2030$ farming systems. $L I-F S_{2030} i$ : Labour intensity of the type $i 2030$ farming system.

\subsubsection{The Processing Industry Level}

Similarly to the farm level, the analysis at the industry level proceeds in three steps: establishing the baseline, defining scenario assumptions, evaluating the impacts. Two aspects are specific to the processing industry. First, in a given sector several types of industry co-exist, each one of these using raw products in a certain way, with a certain labour (and capital) intensity, to produce intermediary or end-products. Those different sub-sectors need to be distinguished from each other. In the same way, the physical fluxes passing from the farm to the different types of industries need to be reconstructed. Second, and differently to the farm level, national data is only available at the sub-sector level (i.e., no publicly available data for a sample of factories, as the FADN data does for farms), for which aggregated key indicators are given: number of factories per average size, total number of employees in full time equivalent (FTE), fixed assets, value added generated, etc. The grain of analysis is thus much rougher at the industry level than at the farm level.

The establishment of the baseline aims at reconstructing the industry structure by sub-sectors: identifying physical fluxes between the farm level and each sub-sector, and characterizing the physical labour intensity of each sub-sector, expressed in FTE per ton of milk. The following equations are used:

$$
\mathrm{V}_{\mathrm{i} 2015}=\mathrm{C}_{2015} \times \alpha_{\mathrm{i} 2015}
$$

where $\mathrm{V}$ is the volume of milk used to produce the processed product $_{\mathrm{i}}$ (milk, cream, butter, yoghurt, cheese, milk powder), $\mathrm{C}$ the milk collection volume and $\alpha$ the coefficient that determines the share of milk used in each sub-sector. The same is done for the secondary processing level with the $B$ coefficient (Figure 4). 


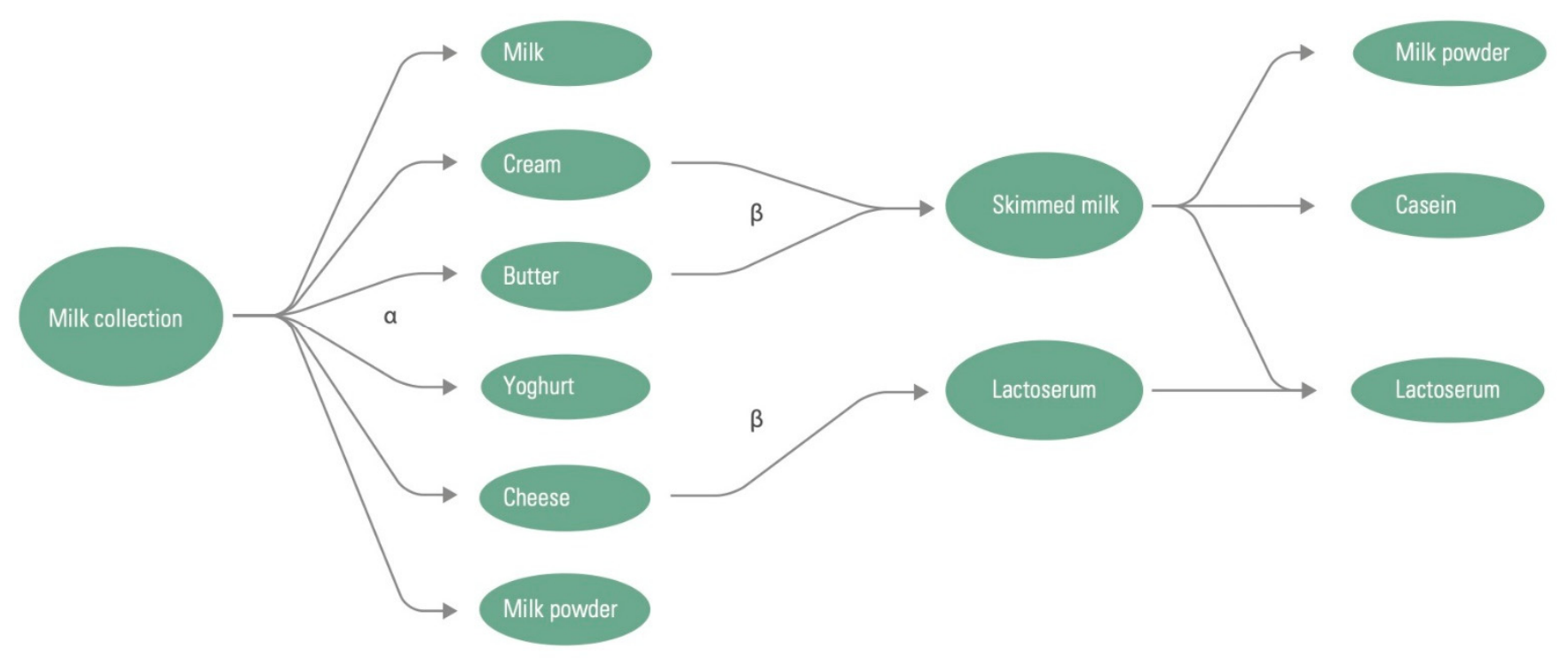

Figure 4. The structure of the milk industry as reconstructed in IAA_Calc.

The labour intensity of each sub-sector for the baseline $\left(\mathrm{LI}_{\mathrm{i}} 2015\right)$ is calculated based on volumes calculated through (3) and the number of employees as given in the public statistics, following Equation (4):

$$
\mathrm{LI}_{\mathrm{i} 2015}=\mathrm{L}_{\mathrm{i} 2015} / \mathrm{V}_{\mathrm{i} 2015}
$$

The second step consists in deriving quantitative assumptions for $\alpha_{i 2030}$ (and $\beta_{i}$ 2030) and $\mathrm{LI}_{\mathrm{i}} 2030$, given that $\mathrm{C}_{2030}$ is a direct result of the assumptions made at the farm level. Both $\alpha_{\mathrm{i} 2030}$ and $\mathrm{LI}_{\mathrm{i} 2030}$ depend on market dynamics that can only be hypothesised based on qualitative storylines. How much milk will be transformed into liquid milk vs. cheese vs. cream, etc., and whether the labour intensity of the production will be lower or higher in 2030 than in 2015 will indeed depend on what consumers will be willing to buy on the domestic market and on competitive dynamics.

Based on (3) and (4), the assumptions made regarding $\alpha_{i 2030}$ and $\operatorname{LI}_{i 2030}$ enable to calculate the final impact of a given scenario on the employment level at the industry level:

$$
L_{2030}=\sum_{i}\left(\mathrm{LI}_{\mathrm{i} 2030} \times V_{i} 2030\right)
$$

where $V_{i 2030}=\mathrm{C}_{2030} \times \alpha_{\mathrm{i} 2030}$

\section{Result}

In a first paragraph, the storylines of the two scenarios developed are quickly presented, along with the key techno-economic assumptions. Then, their impacts on employment are presented in a second paragraph. Both scenarios have the same level of climate ambition, as set by the French SNBC.

\subsection{Two Contrasted Scenarios}

Storylines for the two scenarios contrast with respect to two key variables identified during stakeholder workshops (see Figure 5):

- the type and number of sustainability issues considered: this variable was considered given the numerous discussions that arose around the priority that should be given to climate mitigation over any others or not, and in particular the role organic/extensive forms of agriculture should be given in a decarbonization scenario (following debates related to land sharing/land sparing-see [30]). The question of farm concentration, 
and whether small farms should be prioritized at all, was also part of that discussion on which outcomes to consider;

- the magnitude and the field in which policy changes occur: this variable was considered to account for the political challenges associated to various scenarios.

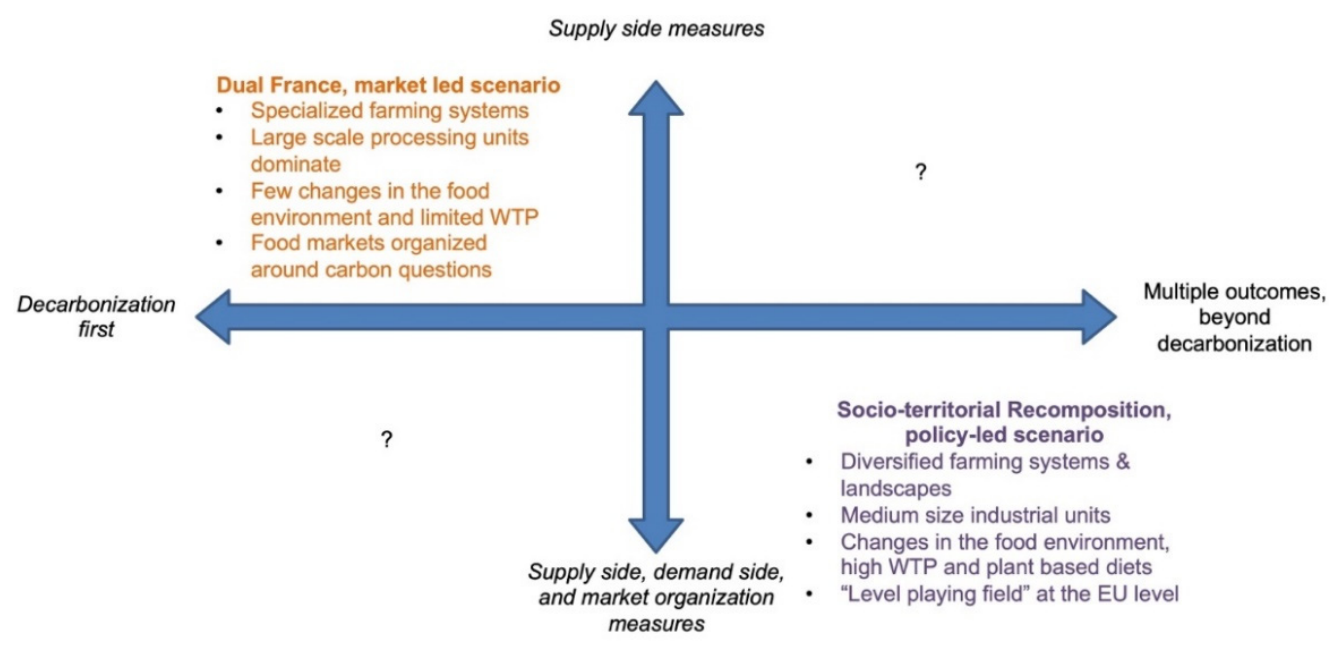

Figure 5. Transition space and positioning of the two scenarios explored.

While theoretically such an approach would yield four potential scenarios, only two were retained in the final discussion for mainly two reasons: the two other scenarios were more difficult to envision (although examples of scenario relying on all types of measure but focusing only on decarbonization exist, see [31]); and given the timeframe of the project, it would have been difficult to run simulations for the four contrasted scenarios.

The "socio-territorial recompositions scenario" envisions changes in the policy framework at all levels (supply, demand, and market organization), to tackle in a systemic way most food system related issues (climate, biodiversity, health), giving full consideration to the EU "Farm to Fork" [13] and "Biodiversity" strategies. Conversely, the Dual France scenario focuses mostly on climate mitigation issues and does so by relying mostly on supply side measures.

More specific assumptions (both qualitative and quantitative) to configure SP_Calc and IAA_Calc regarding the farm, processing industry and consumer levels, as well as regarding trade are derived from those broad scenarios.

\subsubsection{The Socio-Territorial Recompositions Scenario Assumptions}

Farm Level

In this scenario farmers develop strategies aiming to maximize the ecological processes of the agro-system and to strengthen the economic productivity of their farm mainly through product differentiation (economies of scope). The average farm size continues to increase but at a much slower pace than during the 2000-2020 period. The rate of new entrants in the dairy sector also increases compared to the recent period. Since these systems are less input intensive, they are more resilient towards input price shocks. However, because of the large share of grassland, they are vulnerable to potential climatic stress, especially droughts.

\section{Industry Level}

VSEs and SMEs gain market share through effective local marketing techniques, small-scale innovations and consumer interest in rediscovering local products linked to a specific terroir. Conversely, large industrial groups remain focused only on standardized commodities and lose their market share. This translates into a stabilisation of even an increase of the average labour intensity for most products attracting the interest of consumers (local specialty, etc.). The exports of raw and unprocessed products are reduced 
in favour of a better market valorisation for the agricultural products which are sold after a stage of initial or secondary processing made by labour-intensive (and often linked to their production area) local cheese dairies which become key players in this new territorial restructuring.

\section{Consumer Level}

The assumption is that on average, the consumer willingness to pay for higher quality food increases. The share of ultra-processed food (group 4 in NOVA classification) [32,33] in the food basket slow-down and then cease to increase, while locally produced food increases its market share.

\section{Trade}

This scenario relies on two key assumptions: (i) French consumers are ready to purchase the higher value products resulting from the changes at the farm and processing industry level, and not replacing it by cheaper imported products; (ii) French economic actors are able to valorise these same products on the export market in a context where a significant share of the production will still need to be exported.

\subsubsection{The "Dual France" Scenario Assumptions}

Farm Level

In this scenario farms' level of concentration and specialisation continues to increase [34], while environmental imperatives are integrated into farm growth strategies. This leads to farms becoming larger and larger, more and more specialised, with a decreasing trend in the labour intensity of farms. Their high degree of specialisation and the associated high level of indebtedness makes these farms overall less resilient to price shocks [35].

\section{Industry Level}

Following the trend of the last decades, the processing industries continue to increase their specialisation and reduce average costs through economies of scale and the dissociation between primary processing and secondary processing. Secondary processing actors continue to concentrate and increase the volume of their standardised production. This evolution leads to two types of consequences in the food sector.

- First, following a logic of price competitiveness, companies increase their physical productivity (and therefore reduce the labour intensity).

- Secondly, the product mix evolves towards the production of food-ingredients to the expenses of more labour-intensive and less commodified products.

\section{Consumer Level}

Consumer willingness to pay for food continues to decrease. The share of ultraprocessed food in the food basket continues to increase while only the most well-off consumers can afford (and are interested in) "quality" products.

\section{Trade}

The domestic market remains a "captive market" for French economic players in which they continue to face strong competition from importers [36]. On the export market, they are able to better valorise French dairy specialties and in particular cheese [36].

\subsection{Impacts on Employment}

As in all modelling approach of this kind, the results provided in the following sections should be interpreted as orders of magnitude that evaluate the impact of future transition scenarios. These are general estimations based on a transparent scientific exercise rather than an exact prognosis of the future. 


\subsubsection{The Farm Level}

Our results show that despite the reduction in total production a low-carbon and agro-ecological transition reduces the rate of farm loss and preserves more jobs than the current trend. Due to the evolution of the global context, which is more advantageous to the development of innovative strategies aiming to diversification and for more upmarket products, the dairy sector preserves about 8000 farms and 5200 jobs compared to the current trend.

In contrast, in a context where the political support only focuses on the mitigation of climate change and the labour productivity is strengthened, most farmers' strategies will determine a reinforcement of capital/labour substitution and a conspicuous reduction in the number of jobs with potential risks for farmers' income level.

Our analysis shows that in the Dual France scenario the number of farms will be reduced as well as the number of jobs by respectively 7000 and 13,000 units compared to current trends (Figure 6).

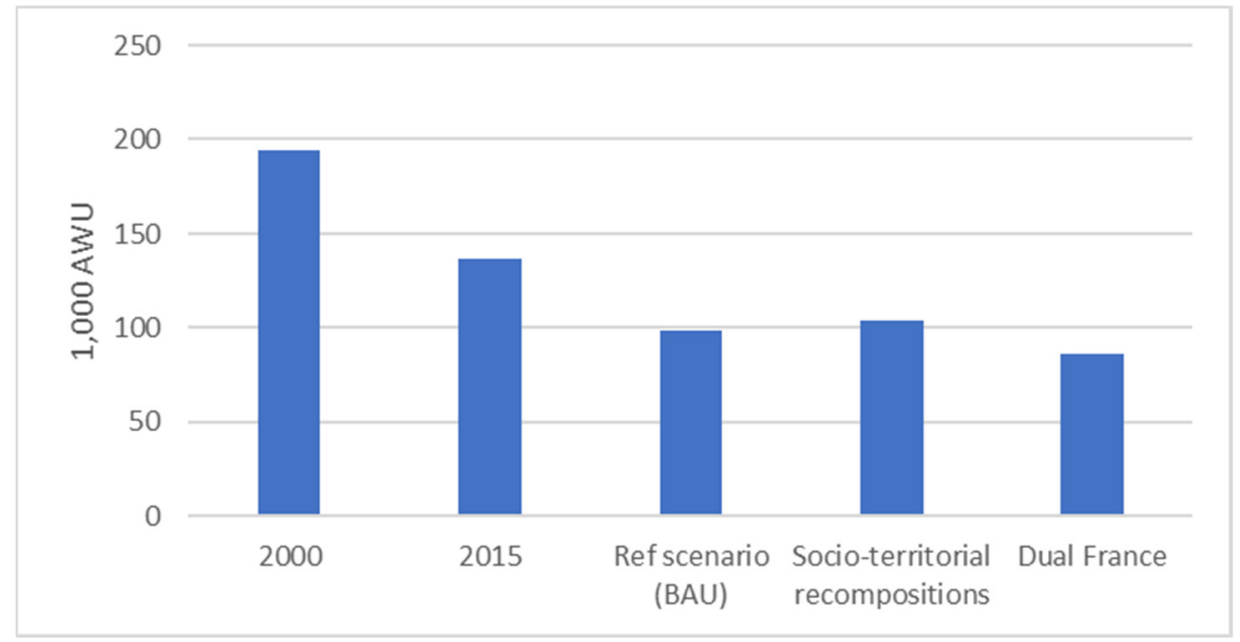

Figure 6. Annual Work Unit (AWU) in dairy farms in 2000, 2015 and in 2030 scenarios (Source: RICA, SP_Calc).

\subsubsection{The Processing Industry Level}

The results of the Socio-territorial recompositions scenario show an increase in the number of jobs in the agri-food industry ( $+12 \%$ compared to 2015 , Figure 7$)$. This is mainly possible through the change in the product mix which offset the decrease in the volume of milk collected in the Socio-territorial recompositions scenario and through the expansion of labour-intensive artisanal producers and of secondary and tertiary industrial processing facilities.

Processing companies develop their strategies towards an increase in cheese production (which is highly labour-intensive in comparison to other processed products) mainly at the expense of butter production.

In contrast with the Socio-territorial recompositions scenario, the Dual France scenario shows a decline in jobs in the dairy sector $(-11 \%)$ despite an increase in the volume of milk going through the agri-food industry. This decline can be explained by two factors. First, there is an overall decrease of labour intensity (between 5 and 10\% compared to 2015) in all subsectors compared to 2015 related to the intensification of production and to adoption of economies of scale.

Second, processors decide to produce relatively more butter and less cheese, the latter being more linked to production in VSEs and SMEs and having a much higher labour intensity. 

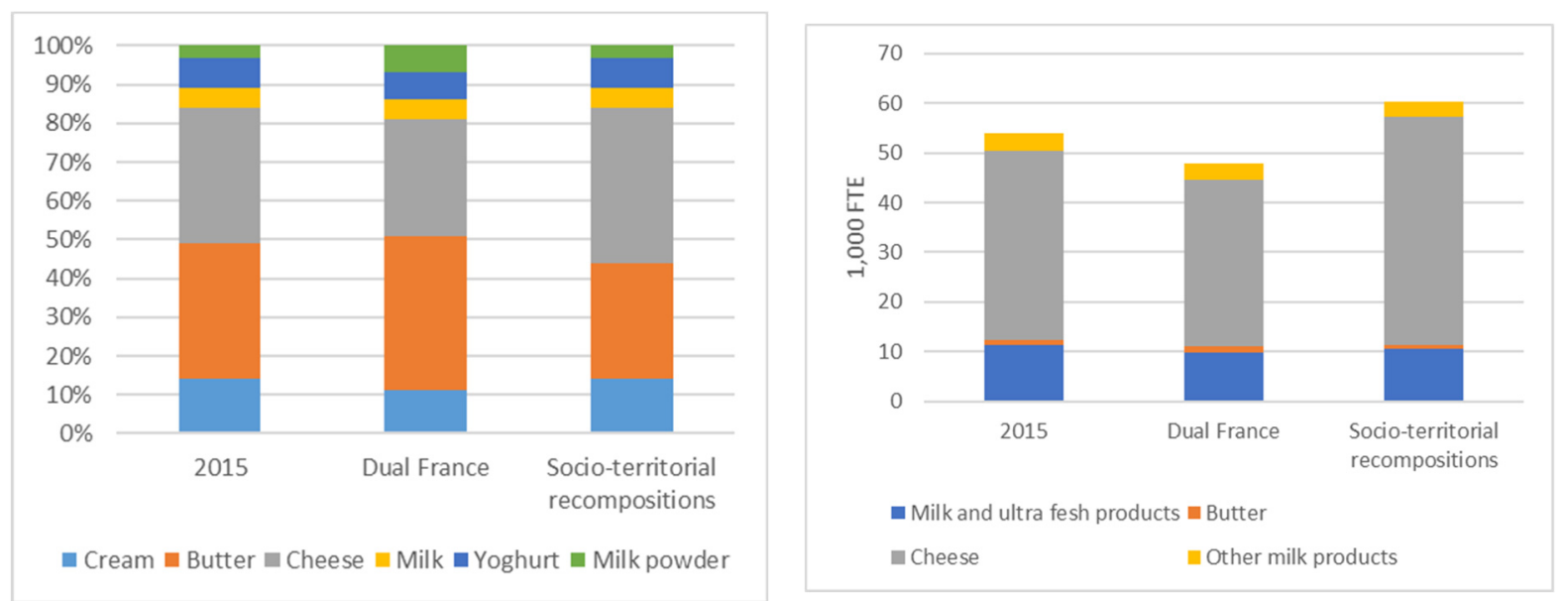

Figure 7. Evolution of the product mix and associated jobs in the dairy sector for the two scenarios Dual France and Socio-territorial recompositions.

\subsection{Sensitivity Analysis}

Table 2 presents a sensitivity analysis for the results of Dual France and Socio-territorial recompositions scenarios on employment in the dairy sector with respect to the French Ministry of Agriculture's business as usual scenario developed during the preparation of the SNBC and two sets of extreme alternative hypotheses: "Employment +" and the "Danish Model":

- Employment + gives great importance to the position of civil society actors [37] in favour of a significant increase in the rate of new farm establishments and a deceleration in farm concentration. In this scenario, small farms (farms having less than 51 dairy cows) account for $75 \%$ of the herd.

- In contrast, the Danish Model generalises the average Danish system to the whole French dairy herd. In this case, the average Danish farm-173 dairy cows for three AWU and a production of 1.6 million litres of milk-is extrapolated to the total French herd envisaged by the SNBC-A in 2030.

Table 2. Hypothesis for 2015 and the 2030 scenarios regarding the volume of milk collected, $\alpha$ and $\beta$ parameters.

\begin{tabular}{|c|c|c|c|}
\hline & 2015 & Socio-Territorial Recompositions & Dual France \\
\hline Milk collection volume (1000 t) & 24,600 & 23,500 & 26,000 \\
\hline \multicolumn{4}{|c|}{$\alpha$} \\
\hline & 2015 & Socio-Territorial Recompositions & Dual France \\
\hline Milk & $5 \%$ & $5 \%$ & $5 \%$ \\
\hline Cream & $14 \%$ & $14 \%$ & $11 \%$ \\
\hline Butter & $35 \%$ & $30 \%$ & $40 \%$ \\
\hline Yoghurt & $8 \%$ & $8 \%$ & $7 \%$ \\
\hline Cheese & $35 \%$ & $40 \%$ & $30 \%$ \\
\hline Milk powder & $3 \%$ & $3 \%$ & $7 \%$ \\
\hline \multicolumn{4}{|c|}{ B } \\
\hline Cream & $83 \%$ & & \\
\hline Butter & $95 \%$ & & \\
\hline Cheese & $80 \%$ & & \\
\hline
\end{tabular}


Additional assumptions on the agri-food component have been made to assess the total employment impact of these two alternative scenarios. In particular, the average employment intensity of the dairy industry decreases by $19 \%$ in the "Danish Model" due to the economies of scale envisaged, while it increases by $25 \%$ in Employment+ to account for the development of on-farm processing.

In the alternative Employment+ scenario, the double objective of preserving the agricultural employment and reducing the emissions of the dairy sector, is based on the great spread of very small farms ( 30 dairy cows or fewer) which would reach $40 \%$ of farms and $27 \%$ of the herd by 2030 . In such a context, since the average productivity per dairy cow of these small farms has a much lower potential for growth than large, highly automated systems, milk production decreases $(18 \%$ less than the Socio-territorial recompositions scenario, or $25 \%$ less compared to 2015). Finally, to ensure sufficient value added, and to remunerate a stable workforce despite the drop in volumes, this scenario requires that around $24 \%$ of the milk produced should be processed directly on the farm (compared to the current $2 \%$ ). Since the milk processed in the farm no longer transits through the industrial sector, this evolution has a huge impact on employment at the processing level. When we look at global results considering the whole agricultural sector, Employment+ is the scenario that generates the most jobs without however preserving the 2015 employment level $(-4 \%)$.

On the contrary, the alternative "Danish Model" scenario focuses on an extreme logic based on concentration, intensification, and specialisation. The results show that at the agricultural level the loss of farms and jobs is extremely high ( $-71 \%$ agricultural jobs than in $2015,-35 \%$ agricultural jobs than the Dual France scenario).

On the other hand, in the processing sector, this scenario maintains the same number of jobs as in 2015. This is explained by the higher performance of "Danish like" farms which increase the volumes of milk collected and more than offset the reduction in employment intensities associated with economies of scale. In total, if we look at the whole sector, this scenario generates the greatest loss of jobs compared to 2015. It should also be mentioned that despite the great climate performances realised through the efficiency gains allowed by the increase in the average size of farms, the impacts of this scenario in terms of food consumption and biodiversity should certainly need to be inspected close, as well as its investment needs.

\section{Discussion}

\subsection{Beyond Jobs: The Multiple Assets of a Just Transition}

By applying our methodological framework to the dairy sector, we show that structural changes in the supply (farm and processing industry levels) lead to moderate decrease in labour intensities that would be sufficient to offset the reduction in volumes of milk production hypothesized by the SNBC projections compared to the reference scenario (see Table 3). Yet, the starting point of the study could be questioned: why should jobs in the dairy sector be maintained? Wouldn't it be more relevant to identify job creation opportunities in emerging sectors, within or outside the agricultural sector? Schumpeterian reasoning affirms that the destruction of jobs in a sector is the logical result of the evolution of the economic system, and that new jobs will be created in emerging and innovative sectors [38]. In such a perspective, it does not matter whether jobs are created within the agri-food sector, in other sub-sectors than the one here considered (e.g., in horticulture, bioenergy, or vegetal protein production), or in totally different sectors (e.g., in the tertiary sector). To that objection, we consider that the evolution in labour intensities at farm and industry levels projected in the Recomposition scenario could not only maintain jobs in rural communities, but also contribute to generate benefits for biodiversity and health. 
Table 3. Sensitivity of the model to alternative assumptions in terms of employment (Source: RICA \& RGA (data 2015) and authors from IAA_Calc and SP_Calc for the scenarios)

\begin{tabular}{|c|c|c|c|c|c|c|c|c|}
\hline & $\begin{array}{c}\text { Average Number } \\
\text { of DC/Farm }\end{array}$ & $\begin{array}{c}\text { Average } \\
\text { Productivity/DC }\end{array}$ & $\begin{array}{l}\text { Milk Production } \\
\text { (bn L) }\end{array}$ & Number of Farms & $\begin{array}{c}\text { Number of } \\
\text { Agricultural Jobs } \\
\text { (AWU) }\end{array}$ & $\begin{array}{c}\text { Number of } \\
\text { Agri-Food Jobs } \\
\text { (FTE) }\end{array}$ & Total Jobs & $\begin{array}{l}\text { Overall Labour } \\
\text { Intensity }\end{array}$ \\
\hline 2015 & 60 & 7014 & 25.6 & 66,000 & 136,000 & 53,875 & 189,875 & 7.4 \\
\hline $\begin{array}{l}\text { Socio-territorial } \\
\text { recompositions } 2030\end{array}$ & 75 & 7313 & 23.4 & 43,000 & 104,000 & 60,223 & 164,223 & 7.0 \\
\hline Current trend 2030 & 100 & 8594 & 27.5 & 35,000 & 98,000 & 57,215 & 155,215 & 5.6 \\
\hline Employment + 2030 & 45 & 5969 & 19.1 & 70,000 & 140,000 & 42,820 & 182,820 & 9.6 \\
\hline
\end{tabular}


Regarding biodiversity, serious evidence points to the fact that small and labourintensive farms in the EU better performs in terms of biodiversity preservation $[39,40]$ thanks to the greater level of landscape heterogeneity and complexity they favour [41-43]. Stabilising farm sizes while increasing the level of diversification at both farms and landscapes levels, as modelled for the Socio-territorial recomposition scenario, would thus not only stabilise labour intensities at the farm level but also deliver on biodiversity.

Regarding health, labour intensity in the processing industry reflects its overall organisation and, as such, what type of foods it produces. Over the last decades, the rationalisation of production processes and the willingness to reduce production costshence labour intensity-has led to the dominance of a "twin movement" of conversion/recomposition [44]-through which raw materials are first transformed into stable and homogeneous ingredients and then re-assembled to make finished-and often ultraprocessed-products [45]. As the share of ultra-processed foods increased in western diets, so did the prevalence of obesity and associated non-communicable diseases [46], with clear correlation within social groups between high level of consumption and high rates of prevalence [32,33]. Against this backdrop, the slight increase in labour intensity in the Recomposition scenario aims at reflecting a development in small to medium scale factories that have control over the whole process of production, from raw material to end-product. Such factories limit the conversion/recomposition process, and their development contribute to gradually reduce the relative share of ultra-processed foods put on the market. As for biodiversity, the Socio-territorial recomposition scenario offers potential to contribute to better health outcomes by reducing the relative importance of ultra-processed foods. However, the question that remains unanswered and which our modelling does not address directly regards the conditions under which the economic viability of such a scenario could be ensured.

\subsection{Policy and Market Challenges to Ensure the Economic Viability of the Recomposition Scenario}

In particular, one of the main questions that this paper raises is about market balance and competitiveness dynamics. A key point in the planning of future scenarios is to analyse if national and international consumers will continue to buy domestic milk and dairy products while they have the possibility to buy cheaper ones produced by neighbouring countries. The answer to this question will probably depend on the public support of domestic demand and the Common market organisation. Dealing with both aspects goes beyond the scope of this paper. What could nevertheless be said is that:

Measures to increase the uptake of more virtuous products on the domestic market exist and are for example: food labelling, public procurement policies, targeted communication towards consumer. However, these measures are not deployed at a full scale now.

Regarding international competition, in a context where over $40 \%$ of the milk produced in France is exported, the key issue is to ensure that operators belonging from different countries pursue similar objectives while they search for price and non-price competitiveness.

While most EU countries share the ambition to decarbonise the food sector, they remain with great discrepancies regarding the means to adopt to achieve this target and which other objectives prioritise. For example, if we consider the Danish Agriculture and Food Council's action plan to decarbonise the Danish dairy sector by 2040, we can see how this strategy follows different logics with respect to the Socio-territorial recompositions scenario. Based on land sparing approach [47], it relies on a high intensification of milk production (with cows averaging 14,000 L/year) to reduce the carbon footprint per ton and a major reduction of farm employment, while the issue of biodiversity preservation is not at the centre of the strategy. If deployed in its current form, the Danish Agriculture and Food Council's action plan will probably increase the price competitiveness differential between Denmark and France [36] (the capital intensity of Danish farms and the very high labour productivity associated with it is more than double than the one observed in Brittany: 513,000 L/AWU in Denmark compared to 206,000 L/AWU in Brittany and Pays 
de Loire [36]). If the risk of import substitution can be considered as low given the captive nature of French dairy market, the possibility that France will lose part of its market share on exports seems very high. This holds true especially if traders' requirements to export agri-food products remain based on standardised and undifferentiated commodities.

In a context of "common market", EU countries should harmonise their vision of what constitutes a sustainable food system to limit internal competition and favour the sort of just transition outlined in the Socio-territorial recompositions scenario.

\subsection{An Innovative Modelling Approach Which Needs Further Development}

At our knowledge, the modelling work presented in this paper is an original attempt to provide a detailed analysis of the socioeconomic effects of systemic transformations in the food system. It brings three major methodological innovations.

Firstly, it provides an analysis based on structural transformations of the production tools in coherence with the objective of maintaining the food system within planetary boundaries, while almost all existing modelling tools are based on the analysis of a marginal change to be applied on constant systems.

Secondly, it considers simultaneously supply and demand. As other similar foresight exercises, this modelling approach makes important assumptions about consumption practices and food regimes to keep the Earth system within the planetary boundaries [48].

Finally, coupling physical balances and socio-economic dynamics, the proposed methodology apprehends the production functions from a strictly physical point of view and answers the question of how many jobs can be generated for a specific amount of production, depending on different production methods. While the objective of such reasoning is not to go back to a system of planned economy, it prevents the dissociation of the physical imperatives linked to the planetary boundaries from socio-economic issues.

We place the proposed modelling work at the centre of the debate between two types of foresight exercises: backcasting approaches having medium to long term time frame which allow the identification of the outlines of a sustainable food system independently of its recent development, but as drawback, give little space for actors on the ground to imagine themselves into the transformations at stake; and short to medium-term foresights, which describe a 5-10-year transition pathways in a more precise manner. They are generally more connected to the actors in the real economy, but since they are strongly associated to current dynamics, they struggle to be ambitious.

Even though the first approach has made it possible to clearly identify the challenges of the transition, its appropriation by a large share of actors in the agri-food sector has so far proved to be much more challenging.

The hope of this paper is that its short and medium-term time frame can be a major lever for bringing ground actors on board for a constructive discussion regarding possible solutions to be adopted for the agri-food system. However, major efforts are still needed to progress in structuring discussions with stakeholders on five aspects:

- The modelling work should consider all key agricultural sector (and not just the dairy sector), and in particular the meat production and horticulture sectors which are highly labour intensive.

- The analysis of the impact of the scenarios on farm income and on the amount of investments at stake for the transition still needs to be implemented in the modelling tool.

- At the processing level, the diversity of possible strategies and their impact on production costs and on consumer prices are not yet taken into fully account since a disaggregation work remains necessary to differentiate processing industries according to their size.

- The inclusion of the retail sector in the quantitative analysis is also necessary to fully grasp the issues of value distribution in all the value chain.

- Finally, a more detailed analysis shedding light on the sequence of policy changes (which policy needs to change first and why) and the politics of policy changes (who 
should act with whom for policy A or B to change given the current state of affairs) will be of utmost importance (following for example [49]).

These five points do not undermine the major areas of change identified in the previous paragraph, which must be considered in the major political projects underway concerning food systems.

Author Contributions: Conceptualization, P.-M.A. and C.A.; methodology, P.-M.A., B.G., C.A.; model development, P.-M.A., B.G., M.S. and C.A.; validation, P.-M.A.; formal analysis, P.-M.A., B.G., É.H., M.S. and C.A.; investigation, P.-M.A., B.G., É.H., M.S. and C.A.; writing-original draft preparation, P.-M.A.; writing - review, M.S. and C.A.; project administration, P.-M.A.; funding acquisition, P.-M.A. All authors have read and agreed to the published version of the manuscript.

Funding: This study has received financial support from: the French government in the framework of the programme "Investissements d'avenir", managed by ANR (the French National Research Agency) under the reference ANR-10-LABX-01. The European Union's Horizon 2020 research and innovation programme under grant agreement No 727243 for the VALUMICS project. The French government through grants received from the Ministry of Agriculture and the Ministry of the Ecological Transition. The Daniel \& Nina Carasso Foundation (Grant n 00095500), The Martine \& Didier Primat Foundation. The Foundation "Terres Solidaires" (Grant n FTS-FR-19-15). The French Agency for Environmental Transition (ADEME). The French Agency for Biodiversity (OFB).

Acknowledgments: Access to some confidential data, on which is based this work, has been made possible within a secure environment offered by CASD-Centre d'accès sécurisé aux données (Ref. 10.34724/CASD). The project underpinning this paper has benefited from the support of a scientific committee made up of the following persons to whom the authors would like to express their deep gratitude: Valentin Bellassen, Philippe Boulet, Pierre-Alain Jayet, Christophe Perrot, Jean-Louis Rastoin, Bernard Valluis. We also would like to thank several colleagues from the BASIC that have greatly contributed to data collection and first analysis, namely Delphine McAdams-Marin and Théodore Fechner.

Conflicts of Interest: The authors declare no conflict of interest. The funders had no role in the design of the study; in the collection, analyses, or interpretation of data; in the writing of the manuscript, or in the decision to publish the results.

\section{References}

1. Poux, X.; Aubert, P.-M. Ten Years for Agroecology in Europe: A Multifunctional Agriculture for Healthy Eating. Findings from the Ten Years for Agroecology (TYFA) Modelling Exercise; Iddri: Paris, France, 2018; p. 73.

2. Billen, G.; Aguilera, E.; Einarsson, R.; Garnier, J.; Gingrich, S.; Grizzetti, B.; Lassaletta, L.; Le Noë, J.; Sanz-Cobena, A. Reshaping the European agro-food system and closing its nitrogen cycle: The potential of combining dietary change, agroecology, and circularity. One Earth 2021, 4, 839-850. [CrossRef]

3. Rockström, J.; Steffen, W.; Noone, K.; Persson, Å.; Chapin, F.S., III; Lambin, E.F.; Lenton, T.M.; Scheffer, M.; Folke, C.; Schellnhuber, H.J. A safe operating space for humanity. Nature 2009, 461, 472. [CrossRef] [PubMed]

4. Campbell, B.M.; Beare, D.J.; Bennett, E.M.; Hall-Spencer, J.M.; Ingram, J.S.I.; Jaramillo, F.; Ortiz, R.; Ramankutty, N.; Sayer, J.A.; Shindell, D. Agriculture production as a major driver of the Earth system exceeding planetary boundaries. Ecol. Soc. 2017, $22,8$. [CrossRef]

5. Aiking, H.; de Boer, J. The next protein transition. Trends Food Sci. Technol. 2020, 105, 515-522. [CrossRef]

6. Huber, É.; Aubert, P.M.; Loveluck, W. Identifying Research Needs for a Sustainable EU Protein Transition; IEEP/European Sustainable Agriculture Dialogue: Brussels, Belgium, 2020.

7. Springmann, M.; Clark, M.; Mason-D'Croz, D.; Wiebe, K.; Bodirsky, B.L.; Lassaletta, L.; de Vries, W.; Vermeulen, S.J.; Herrero, M.; Carlson, K.M.; et al. Options for keeping the food system within environmental limits. Nature 2018, 562, 519-525. [CrossRef]

8. Bryngelsson, D.; Wirsenius, S.; Hedenus, F.; Sonesson, U. How can the EU climate targets be met? A combined analysis of technological and demand-side changes in food and agriculture. Food Policy 2016, 59, 152-164. [CrossRef]

9. Rosemberg, A. Building a Just Transition: The linkages between climate change and employment. Int. J. Labour Res. 2010, 2, 125-161.

10. BLE. Drivers of Change and Development in the EU Livestock Sector; Federal Office for Agriculture and Food: Bonn, Germany, 2019; p. 72.

11. ECSIP. The Competitive Position of the European Food and Drink Industry; Publication office of the European Union: Luxembourg, 2016; Volume 13, p. 161. 
12. Bolduc, N.; Lumbroso, S.; Aubert, P.-M. Behind "less but better meat": Visions, actors and political struggles of the protein transition in Europe. Environ. Sci. Policy 2021. submitted.

13. EC. Farm to Fork Strategy. For a Fair, Healthy and Environmentally-Friendly Food System; European Union: Brussels, Belgium, 2020; p. 22.

14. ECA. Common Agricultural Policy and Climate: Half of EU Climate Spending But Farm Emissions Are Not Decreasing; European Court of Auditors: Luxembourg, 2021.

15. Dorin, B.; Joly, P.-B. Modelling world agriculture as a learning machine? From mainstream models to Agribiom 1.0. Land Use Policy 2020, 96, 103624. [CrossRef]

16. Clark, M.A.; Domingo, N.G.G.; Colgan, K.; Thakrar, S.K.; Tilman, D.; Lynch, J.; Azevedo, I.L.; Hill, J.D. Global food system emissions could preclude achieving the $1.5^{\circ}$ and $2^{\circ} \mathrm{C}$ climate change targets. Science 2020, 370, 705-708. [CrossRef]

17. Schader, C.; Muller, A.; Scialabba, N.E.-H.; Hecht, J.; Isensee, A.; Erb, K.-H.; Smith, P.; Makkar, H.P.S.; Klocke, P.; Leiber, F.; et al. Impacts of feeding less food-competing feedstuffs to livestock on global food system sustainability. J. R. Soc. Interface 2015, 12, 20150891. [CrossRef]

18. Jackson, T. Prosperity without Growth: Economics for a Finite Planet; Earthscan: London, UK, 2009; p. 264.

19. Jackson, T.; Victor, P.A. The Transition to a Sustainable Prosperity-A Stock-Flow-Consistent Ecological Macroeconomic Model for Canada. Ecol. Econ. 2020, 177, 106787. [CrossRef]

20. MTES. Stratégie Nationale Bas-Carbone; Ministère de la Transition Écologique et Solidaire: Paris, France, 2020.

21. Svensson, J.; Waisman, H.; Vogt-Schilb, A.; Bataille, C.; Aubert, P.-M.; Jaramilo-Gil, M.; Angulo-Paniagua, J.; Arguello, R.; Bravo, G.; Buira, D.; et al. A low GHG development pathway design framework for agriculture, forestry and land use. Energy Strategy Rev. 2021, 37, 100683. [CrossRef]

22. Pellerin, S.; Bamière, L.; Angers, D.; Béline, F.; Benoit, M.; Butault, J.-P.; Chenu, C.; Colnenne-David, C.; De Cara, S.; Delame, N.; et al. Identifying cost-competitive greenhouse gas mitigation potential of French agriculture. Environ. Sci. Policy 2017, 77, 130-139. [CrossRef]

23. Galko, E.; Jayet, P.A. Economic and environmental effects of decoupled agricultural support in the EU. Agric. Econ. 2011, 42, 605-618. [CrossRef]

24. Jackson, T.; Victor, P. Productivity and work in the 'green economy': Some theoretical reflections and empirical tests. Environ. Innov. Soc. Transit. 2011, 1, 101-108. [CrossRef]

25. Bâ, M.; Gresset-Bourgeois, M.; Quirion, P. L'effet sur l'emploi d'une transition écologique de l'agriculture en France. Courr. De L'environnement De l'INRA 2016, 66, 93-103.

26. Couturier, C.; Charru, M.; Doublet, S.; Pointereau, P.; Solagro. Pointereau, P. Le Scénario Afterres 2050 Version 2016; Solagro: Toulouse, France, 2016; p. 93.

27. Gac, A.; Perrot, C.; Mosnier, C.; Chambaut, H.1.n.; Lorilloux, A.; Dollé, J.-B. GESEBOV. Emissions de Gaz à Effet de Serre et Consommations D'énergie de la Ferme Bovine française: Bilan 1990, 2010 et Perspectives 2035—Rapport de Synthèse; IDELE-INRA— ADEME: Paris, France, 2016; p. 26.

28. Cochet, H. The systeme agraire concept in francophone peasant studies. Geoforum 2012, 43, 128-136. [CrossRef]

29. Cerfrance. Stratégie 2030—Comment Rester Dans la Course? Conseil National du Réseau Cerfrance: Paris, France, 2019.

30. Phalan, B. What Have We Learned from the Land Sparing-sharing Model? Sustainability 2018, 10, 1760. [CrossRef]

31. Searchinger, T.D. A Pathway to Carbon Neutral Agriculture in Denmark; World Resources Institute: Washington, DC, USA, 2021; p. 166.

32. Schnabel, L.; Kesse-Guyot, E.; Allès, B.; Touvier, M.; Srour, B.; Hercberg, S.; Buscail, C.; Julia, C. Association Between Ultraprocessed Food Consumption and Risk of Mortality Among Middle-aged Adults in France. JAMA Intern. Med. 2019, 179, 490-498. [CrossRef] [PubMed]

33. Monteiro, C.A.; Cannon, G.; Lawrence, M.; da Costa Louzada, M.L.; Pereira Machado, P. Ultra-Processed Foods, Diet Quality, and Health Using the NOVA Classification System; FAO: Rome, Italiy, 2019.

34. Clay, N.; Garnett, T.; Lorimer, J. Dairy intensification: Drivers, impacts and alternatives. Ambio 2020, 49, 35-48. [CrossRef] [PubMed]

35. Lin, B.B. Resilience in Agriculture through Crop Diversification: Adaptive Management for Environmental Change. BioScience 2011, 61, 183-193. [CrossRef]

36. Perrot, C.; Chatellier, V.; Gouin, D.-M.; Richard, M.; You, G. Le secteur laitier français est-il compétitif face à la concurrence européenne et mondiale? Économie Rurale. Agric. Aliment. Territ. 2018, 364, 109-127. [CrossRef]

37. Girod, N.; Gaiji, K.; Trouvé, A.; Bukhari de Pontual, S.; Bouin, F.; Bellanger, R.; Grandjean, A.; Teste, B.; Julliard, J.-F.; Boulongne, E.; et al. La souveraineté alimentaire sera paysanne ou ne sera pas. Libération 2020, 12.

38. Aghion, P.; Howitt, P. Growth and Unemployment. Rev. Econ. Stud. 1994, 61, 477-494. [CrossRef]

39. Hass, A.L.; Kormann, U.G.; Tscharntke, T.; Clough, Y.; Baillod, A.B.; Sirami, C.; Fahrig, L.; Martin, J.-L.; Baudry, J.; Bertrand, C.; et al. Landscape configurational heterogeneity by small-scale agriculture, not crop diversity, maintains pollinators and plant reproduction in western Europe. Proc. R. Soc. B Biol. Sci. 2018, 285, 20172242. [CrossRef]

40. Š́álek, M.; Hula, V.; Kipson, M.; Daňková, R.; Niedobová, J.; Gamero, A. Bringing diversity back to agriculture: Smaller fields and non-crop elements enhance biodiversity in intensively managed arable farmlands. Ecol. Indic. 2018, 90, 65-73. [CrossRef] 
41. Benton, T.G.; Vickery, J.A.; Wilson, J.D. Farmland biodiversity: Is habitat heterogeneity the key? Trends Ecol. Evol. 2003, 18, 182-188. [CrossRef]

42. Fahrig, L.; Baudry, J.; Brotons, L.; Burel, F.G.; Crist, T.O.; Fuller, R.J.; Sirami, C.; Siriwardena, G.M.; Martin, J.L. Functional landscape heterogeneity and animal biodiversity in agricultural landscapes. Ecol. Lett. 2011, 14, 101-112. [CrossRef]

43. Dainese, M.; Martin, E.A.; Aizen, M.A.; Albrecht, M.; Bartomeus, I.; Bommarco, R.; Carvalheiro, L.G.; Chaplin-Kramer, R.; Gagic, V.; Garibaldi, L.A.; et al. A global synthesis reveals biodiversity-mediated benefits for crop production. Sci. Adv. 2019, 5, 13. [CrossRef]

44. Soler, L.-G.; Réquillart, V.; Trystram, G. Organisation industrielle et durabilité. In duALIne. Durabilité de L'alimentation Face à de Nouveaux Enjeux. Questions à la Recherche; Esnouf, C., Russel, M., Bricas, N., Eds.; INRA-Cirad: Paris, France, 2011 ; pp. 85-95.

45. Baker, P.; Machado, P.; Santos, T.; Sievert, K.; Backholer, K.; Hadjikakou, M.; Russell, C.; Huse, O.; Bell, C.; Scrinis, G.; et al. Ultra-processed foods and the nutrition transition: Global, regional and national trends, food systems transformations and political economy drivers. Obes. Rev. 2020, 21, e13126. [CrossRef] [PubMed]

46. Monteiro, C.A.; Moubarac, J.-C.; Levy, R.B.; Canella, D.S.; da Costa Louzada, M.L.; Cannon, G. Household availability of ultra-processed foods and obesity in nineteen European countries. Public Health Nutr. 2011, 21, 18-26. [CrossRef] [PubMed]

47. Danish Agriculture \& Food Council. Neutralité Climatique en 2050; Danish Agriculture \& Food Council: Brussels, Belgium, 2019; p. 25.

48. Saujot, M.; Le Gallic, T.; Waisman, H. Lifestyle changes in mitigation pathways: Policy and scientific insights. Environ. Res. Lett. 2020, 16, 015005. [CrossRef]

49. Markard, J.; Suter, M.; Ingold, K. Socio-technical transitions and policy change-Advocacy coalitions in Swiss energy policy. Environ. Innov. Soc. Transit. 2016, 18, 215-237. [CrossRef] 